\title{
CLINICAL EVALUATION OF THE PRESSOR ACTIVITY OF METHEDRINE, NEO-SYNEPHRINE, PAREDRINE, AND PHOLEDRINE
}

\author{
BY \\ FREDERICK PRESCOTT \\ From the Wellcome Research Institution, London \\ Received October 10, 1944
}

Recently a number of pressor drugs of the adrenaline type have come into clinical use for the treatment of low blood pressure following surgical procedures, spinal anæsthesia, circulatory collapse, and surgical and traumatic shock. For therapeutic purposes the ideal pressor drug should be effective by the intramuscular or intravenous route; it should act rapidly; it should produce a sustained elevation of blood pressure, so that frequent injections of the drug are not necessary; and it should have no undesirable effects on the cardiovascular system and no untoward side effects. Adrenaline and ephedrine were the first drugs to be used clinically to raise the blood pressure in cases of operative shock. Their limitations, however, are now well known. Adrenaline may do more harm than good because in therapeutic doses intravenously it causes a considerable rise of blood pressure, e.g. $200 \mathrm{~mm}$. to $300 \mathrm{~mm}$. of mercury, with a precipitous fall after a few minutes to a level lower than before. Similarly ephedrine, which for dependable results must be given intravenously, produces a sharp rise of blood pressure that lasts only for ten to twenty minutes. Other pressor drugs have been introduced with a more sustained action. In most of the studies reported on these, however, no definite criteria seem to have been employed in their evaluation, nor have the conditions of administration been standardized. In general the drugs have been given to patients showing a fall of blood pressure after spinal anæsthesia or during surgical operations, but few comparative studies have been made on them.

In this investigation an attempt has been made to evaluate in similar conditions the pressor activity of the sympatho-mimetic drugs methedrine ( $d$-desoxyephedrine, pervitin), neosynephrine, paredrine, and pholedrine (paredrinol, veritol). Their chemical relationship to adrenaline and ephedrine is shown in the following formulæ:

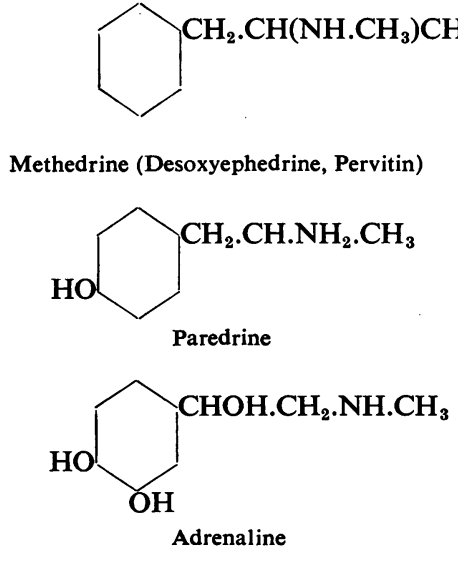

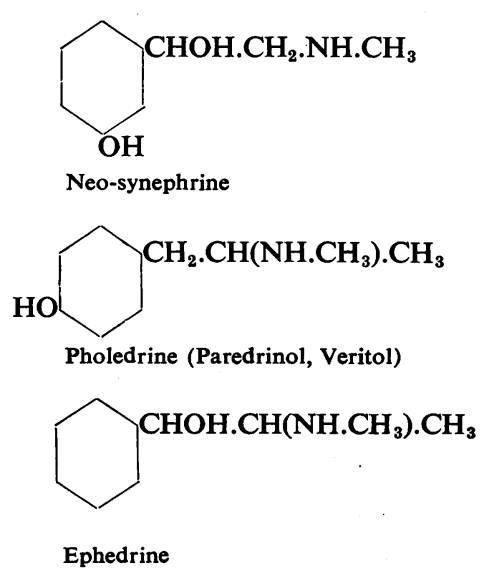


A detailed study of the pressor effects of methedrine has already appeared (Dodd and Prescott, $1943 a$ and 1943b). The results of twenty of the cases studied are given in this paper, only those showing a severe fall in blood pressure (average $64 / 50 \mathrm{~mm}$.) being included.

A number of studies on neo-synephrine have been published (Johnson, 1937; Lorhan and Oliverio, 1938; Bittrich, 1939; Brunner and de Takats, 1939; Silvers and Leonard, 1940; Lorhan and Lalich, 1940; Difabio, Lawrence, and Ascione, 1941) but no comparative clinical tests have been made using patients with a low blood pressure.

Several investigations have been carried out on the pressor activity of paredrine in normal subjects (Abbott and Henry, 1937; Loman, Rinkel, and Myerson, 1939; Altschule and Iglauer, 1940; Iglauer and Altschule, 1940; Myerson and Loman, 1941). Iglauer and Molle (1943) have reported on the pressor effect of paredrine on subjects suffering from infection, but most of them seemed to have a normal blood pressure and were in no need of a pressor drug. It would seem that the best way to evaluate a pressor drug is to give it to a subject with a low blood pressure and see if this can then be maintained at a normal level.

Nathanson et al. (1942) investigated the effect of paredrine in spinal anæsthesia. They recorded that the blood pressure was maintained during the operation in 83 per cent of 114 patients who received the drug. In the author's opinion it is not sufficient to follow the blood pressure during the operation only, say, for half to three-quarters of an hour, as the effect of some drugs does not last longer than this and a fall of blood pressure occurs when the patients are returned to the wards. In evaluating a pressor drug readings must be taken over a period of at least two hours. Altschule and Gilman (1939) also used paredrine to prevent a fall of blood pressure during spinal anæsthesia. Only one case was observed in which a satisfactory rise of blood pressure was recorded for more than two hours.

Pholedrine (veritol) has been used since 1937 on the continent to maintain blood pressure during surgical operations. It has been the subject of favourable reports by Dodd and Merton (1939), Dodd (1940, 1942), and Landau, Logue, and Kopelman (1942). In the author's series it was found that the duration of action of pholedrine was only 35 minutes and that repeated injections of the drug were necessary to maintain the blood pressure when this had fallen to $80 \mathrm{~mm}$. systolic or less. In only four cases out of twenty was the response satisfactory according to the standards laid down by the author. Nathanson and Engelberg (1942) state that paredrine shows a greater and more prolonged pressor activity than pholedrine in the normal subject.

\section{Methods UsED}

The drugs were administered to patients undergoing major operations who experienced a severe fall in blood pressure. The criterion of this was a fall of systolic blood pressure to $80 \mathrm{~mm}$. or less, or a pulse pressure of $10 \mathrm{~mm}$. or less, that persisted for more than twenty minutes to half an hour. If the systolic or pulse pressure showed signs of spontaneous recovery in this period no pressor drug was given.

Whilst it was difficult to standardize exactly the conditions in which the drugs were given, these were much the same for all the patients. Most of the operations were done under spinal anæsthesia, or under local anæsthesia reinforced with an inhalation anæsthetic or with pentothal; a major operation, usually abdominal, was performed in all cases; and the average age was the same in all groups (about 50). The operations included those on the kidney, bladder, and ureter; cholecystectomy; gastrectomy; gastro-enterostomy; laparotomy; excision of the rectum; prostatectomy; radical mastectomy; hysterectomy; lobectomy; and repair of hernia. In most cases the drug was administered intramuscularly; in a few it was given both intramuscularly and intravenously. The intramuscular route was generally chosen because patients with a low pressure and impending shock often have collapsed veins and valuable time may be lost trying to enter them to give an intravenous injection. An efficient pressor drug should, therefore, act quickly when given intramuscularly. 
No injections were given subcutaneously as it is well known that absorption from the subcutaneous tissues is slow in circulatory failure.

Each drug was given to a group of twenty patients undergoing major surgical operations, selected according to the criteria laid down above. The following were evaluated for each drug: optimum dose to produce an adequate pressor response; systolic and diastolic blood pressures before, and maximum and minimum pressures after administration of the drug; rise of systolic and pulse pressure; time for the drug to act; time taken for the systolic blood pressure to return to its pre-operative level; time taken to produce the maximum rise of blood pressure; effect on pulse rate; duration of action; the number of injections needed to sustain the blood pressure; and any untoward effects. Blood pressure and pulse readings were taken every one to two minutes until the maximum rise was recorded and then further readings were made every five minutes for the first hour and every ten minutes for the second hour. When time permitted readings were taken over a period of several hours.

Certain arbitrary standards were adopted. The time taken for the drug to act was measured by the time between the injection and a rise of $10 \mathrm{~mm}$. systolic pressure. Duration of action was measured by the time the systolic pressure kept above $100 \mathrm{~mm}$. The result of an injection was only rated as satisfactory if the systolic pressure kept above $100 \mathrm{~mm}$. for two hours or more and the pulse pressure was not less than $30 \mathrm{~mm}$. during this period. If a period longer than two hours is taken it is difficult to rule out natural recovery after this time in some of the cases, particularly if the fall in blood pressure is due to the administration of a spinal anæsthetic. It was generally found that, if the blood pressure fell during an operation as a result of spinal anæsthesia and surgical trauma, it did so within half an hour to forty minutes of the start of the operation. It is not only spinal anæsthesia that causes a fall in blood pressure but the added effect of surgical trauma (Papper et al., 1943).

\section{RESULTS}

The results are summarized in Table I and presented graphically in Fig. 1. Protocols giving the results of each case and submitted with the paper have been omitted owing to lack of space. The results given in Table I are averages calculated from data obtained from the twenty cases studied with each drug. The blood pressure curves in Fig. 1 were obtained by plotting the average blood pressure of twenty cases calculated at five-minute intervals.

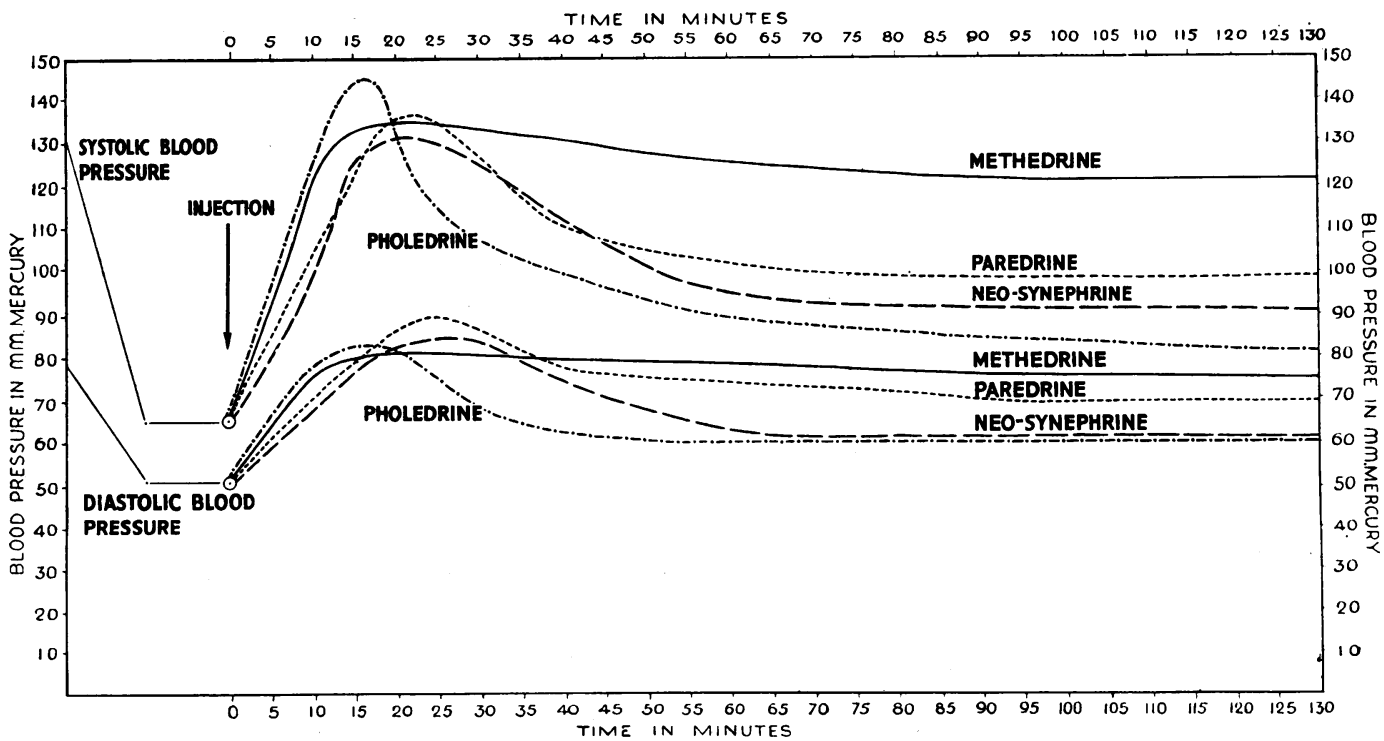

FIG. 1.-Systolic and diastolic blood pressure curves after intramuscular injection of methedrine, neo-synephrine, paredrine, and pholedrine, into surgical patients with low blood pressure. Curves are based on average values of twenty cases for each drug. 
TABLE I

Effect of Methedrine, Neo-synephrine, Paredrine, ANd Pholedrine on Blood Pressure and Pulse Rate. Averages of Twenty Cases

\begin{tabular}{|c|c|c|c|c|c|c|c|c|c|c|}
\hline Drug & & $\begin{array}{c}\text { Dose } \\
\text { in } \\
\text { mg. }\end{array}$ & $\begin{array}{l}\text { B.P. } \\
\text { before } \\
\text { opera- } \\
\text { tion }\end{array}$ & $\begin{array}{l}\text { B.P. } \\
\text { just } \\
\text { before } \\
\text { giving } \\
\text { drug }\end{array}$ & $\begin{array}{l}\text { Max. } \\
\text { B.P. } \\
\text { after } \\
\text { giving } \\
\text { drug }\end{array}$ & $\begin{array}{l}\text { Final } \\
\text { B.P. } \\
\text { after } \\
\text { giving } \\
\text { drug }\end{array}$ & $\begin{array}{c}\text { Increase } \\
\text { or } \\
\text { decrease } \\
\text { in pulse } \\
\text { rate per } \\
\text { min. }\end{array}$ & $\begin{array}{l}\text { Time } \\
\text { to } \\
\text { act } \\
\text { (min.) }\end{array}$ & $\begin{array}{c}\text { Time to } \\
\text { produce } \\
\text { max. } \\
\text { rise in } \\
\text { B.P. } \\
\text { (min.) }\end{array}$ & $\begin{array}{l}\text { Dura- } \\
\text { tion of } \\
\text { action } \\
\text { (min.) }\end{array}$ \\
\hline Methedrine & . & $20-30$ & $127 / 78$ & $64 / 50$ & $134 / 80$ & $122 / 74$ & +16 & $3-4$ & 17 & $\begin{array}{c}\text { Over } \\
120 \text { in } \\
18 / 20\end{array}$ \\
\hline Neo-synephrine & . & $5-7 \cdot 5$ & $125 / 75$ & $64 / 50$ & $132 / 83$ & $91 / 62$ & -11 & 8 & 23 & 42 \\
\hline Paredrine & . & $10-20$ & $132 / 81$ & $67 / 53$ & $136 / 90$ & $99 / 70$ & +15 & $5-6$ & 25 & 60 \\
\hline Pholedrine & .. & $20-30$ & $133 / 80$ & $73 / 50$ & $145 / 84$ & $84 / 62$ & +38 & 4 & 18 & 35 \\
\hline
\end{tabular}

Dosage. The actual dose of the drug required to produce an adequate pressor response is not of great importance, unless such a dose is near the toxic level or produces unpleasant side reactions. Many pressor drugs have been evaluated in terms of the minimal dose required to produce a pressor response, the drug which produces the required response in the smallest dose being rated as the most potent. The duration of action, which is important clinically is often overlooked. In this investigation it was found that the following doses were approximately equipressor in activity when given intramuscularly:

\begin{tabular}{|c|c|c|c|c|c|c|}
\hline Neo-synephrine & . & & .. & & $5 \mathrm{mg}$. to 7 & $7.5 \mathrm{mg}$. \\
\hline Paredrine . & - & .. & . & . & $10 \mathrm{mg}$. to 20 & $\mathrm{mg}$ \\
\hline Methedrine & . & $\ldots$ & $\ldots$ & $\ldots$ & $20 \mathrm{mg}$. to 30 & $\mathrm{mg}$ \\
\hline Pholedrine & .. & .. & $\ldots$ & . & $20 \mathrm{mg}$. to 30 & $\mathrm{mg}$. \\
\hline
\end{tabular}

Repeated administration is usually necessary in the case of pholedrine and neo-synephrine to maintain a blood pressure that has fallen. Out of 20 cases repeated injections were needed in 17 patients treated with pholedrine; in 13 treated with neo-synephrine; in 12 treated with paredrine; and in 2 treated with methedrine.

Effect on Systolic Pressure. All four drugs exert an appreciable action on the systolic blood pressure (Fig. 1). The averages for the maximum systolic blood pressure, the final systolic pressure when the last reading was taken, and the final rise in systolic pressure are given below.

\begin{tabular}{|c|c|c|c|c|}
\hline & & $\begin{array}{l}\text { Average maximum } \\
\text { systolic blood } \\
\text { pressure in } \mathrm{mm} . \mathrm{Hg}\end{array}$ & $\begin{array}{l}\text { Average final } \\
\text { systolic blood } \\
\text { pressure in mm. } \mathrm{Hg}\end{array}$ & $\begin{array}{l}\text { Average final rise } \\
\text { in systolic blood } \\
\text { pressure in } \mathrm{mm} . \mathrm{Hg}\end{array}$ \\
\hline Methedrine .. & $\ldots$ & 134 & 122 & 58 \\
\hline Paredrine $\quad .$. & .. & 136 & 99 & 32 \\
\hline Neo-synephrine & $\ldots$ & 132 & 91 & 27 \\
\hline Pholedrine .. & .. & 145 & 84 & 11 \\
\hline
\end{tabular}

It is seen that whereas pholedrine produces the largest immediate rise this is not maintained, the final systolic pressure being only $84 \mathrm{~mm}$. and the final rise in systolic blood pressure only $11 \mathrm{~mm}$. Methedrine produced the highest final systolic pressure and the highest rise in systolic pressure. This was the difference between the systolic pressure just before the drug was injected and the final reading.

Methedrine was the only drug that kept the systolic blood pressure consistently above $100 \mathrm{~mm}$.

Effect on Pulse Pressure. The pulse pressure is the difference between the systolic and diastolic blood pressures, and is a measure of the force with which blood is pumped from the 
heart into the blood vessels. In shock or impending shock it is low. The normal pulse pressure is about $40 \mathrm{~mm}$. In this study a pressor drug was rated satisfactory only if it maintained a systolic pressure of $100 \mathrm{~mm}$. or more and a pulse pressure of at least $30 \mathrm{~mm}$. The maximal and final pulse pressures and the immediate and final rise in pulse pressure are given below.

$\begin{array}{llcccc} & \begin{array}{c}\text { Average maximum } \\ \text { pulse pressure } \\ \text { in mm. }\end{array} & \begin{array}{c}\text { Average final } \\ \text { pulse pressure } \\ \text { in mm. }\end{array} & \begin{array}{c}\text { Average immediate } \\ \text { rise in pulse } \\ \text { pressure in mm. }\end{array} & \begin{array}{c}\text { Average final rise } \\ \text { in pulse pressure } \\ \text { in mm. }\end{array} \\ \begin{array}{llccc}\text { Methedrine } \\ \text { Neo-synephrine }\end{array} & 54 & 48 & 40 & 34 \\ \text { Paredrine } & . & 49 & 29 & 35 & 15 \\ \text { Pholedrine } & . & 46 & 29 & 32 & 15 \\ \text {. } & 61 & 22 & 40 & 1\end{array}$

Methedrine produced the greatest rise in pulse pressure $(40 \mathrm{~mm}$.) and within limits this was maintained $(34 \mathrm{~mm}$.). With the other drugs the pulse pressure eventually dropped to less than $30 \mathrm{~mm}$. The least satisfactory drug from the point of view of permanently raising the pulse pressure was pholedrine.

Effect on Pulse Rate. Methedrine, pholedrine, and paredrine increase the heart rate; neosynephrine slows it. The average figures and ranges are given below.

\begin{tabular}{|c|c|c|c|c|}
\hline & & & \multicolumn{2}{|c|}{ Effect of pulse rate per minute } \\
\hline & & & Average & Range \\
\hline Methedrine .. & & .. & +16 & -10 to +36 \\
\hline Neo-synephrine & .. & .. & -11 & -35 to +46 \\
\hline Paredrine $\quad .$. & .. & .. & +15 & -24 to +48 \\
\hline Pholedrine & $\cdots$ & 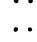 & +38 & -40 to +80 \\
\hline
\end{tabular}

Actually the effect is variable and unpredictable. Methedrine which normally quickens the heart rate may slow it in some patients, and neo-synephrine which normally slows it, may quicken it in some.

Speed of Action. The time taken for the drug to start acting was taken as the time for a rise of $10 \mathrm{~mm}$. systolic blood pressure to occur. The average time taken for the systolic blood pressure to return to its original level and the average time to produce the maximum rise in systolic blood pressure were also noted. The average times are given below.

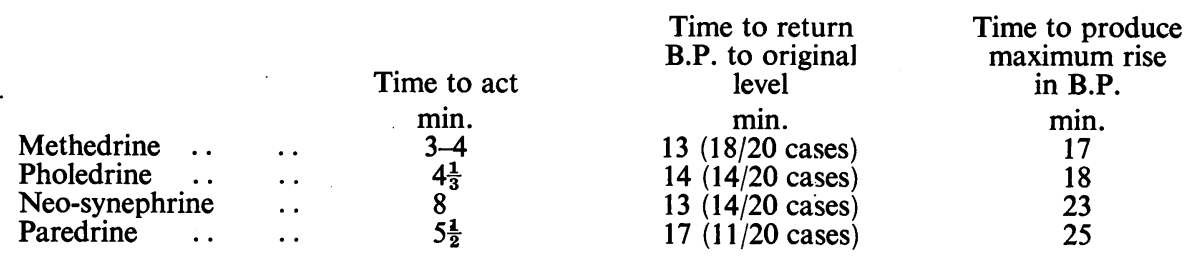

Methedrine and pholedrine appear to act most rapidly, then neo-synephrine, and finally paredrine.

Duration of Action. The drug with the most prolonged action was methedrine. In 18 out of 20 cases the duration of action was over two hours. Only 2 cases were recorded in which the drug failed to maintain the blood pressure above $100 \mathrm{~mm}$. systolic or the pulse pressure at $30 \mathrm{~mm}$. or more for two hours.

Next in order came paredrine. The average duration of action in the 20 cases was 60 minutes. In only 8 out of 20 cases, however, was the effect prolonged for two hours or more.

The duration of action of neo-synephrine averaged 42 minutes in the 20 cases. In 13 of them it averaged 30 minutes. In only 7 cases out of 20 was the effect prolonged for two hours or more.

Pholedrine was the most evanescent of the four drugs in its action. The average duration 
of action was 35 minutes. In only 4 cases out of 20 was the effect of the drug prolonged for two hours.

\section{REACTIONS FROM THE DRUgS}

The commonest side effect produced by these drugs is a disturbance of cardiac rhythm and the production of systolic heart murmurs. These effects are transient and usually do not last for more than a few hours. In each patient the cardiovascular system was examined clinically before and after giving the drug. The fewest cardiac disturbances were experienced with methedrine and the most with neo-synephrine. The results are summarized below.

\begin{tabular}{|c|c|c|c|c|}
\hline & & $\begin{array}{c}\text { Extrasystoles and } \\
\text { other disturbances } \\
\text { of rhythm }\end{array}$ & $\begin{array}{c}\text { Apical and } \\
\text { pulmonary systolic } \\
\text { murmurs }\end{array}$ & $\begin{array}{l}\text { Altered heart } \\
\text { sounds }\end{array}$ \\
\hline Neo-synephrine & .. & 5 & 3 & 1 \\
\hline Pholedrine $\quad$. & .. & 5 & 2 & - \\
\hline Paredrine & .. & 3 & 4 & - \\
\hline Methedrine & .. & 2 & 1 & - \\
\hline
\end{tabular}

The bradycardia produced by neo-synephrine may result in a pulse rate as low as 30 a minute, according to Brunner and de Takats (1939), who have recorded partial heart block after administering the drug. No untoward effects of this nature were observed with neosynephrine in this study.

Electrocardiograms were taken in four persons receiving methedrine, but no significant changes were observed. The cardiogram was normal the day after the author received a dose of $70 \mathrm{mg}$. intramuscularly in divided doses. Unfortunately there were no facilities for taking cardiograms with the other drugs.

Methedrine appears to be the only one of the four pressor drugs with a marked stimulating effect on the cortical centres. This is in the normal person. The effect was not noticed in patients submitted to surgical operations, being presumably neutralized by the premedication with morphine, the anæsthetic, and the post-operative morphine, which was usually given afterwards to patients undergoing major operations.

\section{Summary AND Conclusions}

The clinical effectiveness of four pressor drugs, methedrine (pervitin, $d$-desoxyephedrine), paredrine, neo-synephrine, and pholedrine (veritol, paredrinol) has been examined. Each drug was tested on twenty patients showing a severe fall in blood pressure (to $80 \mathrm{~mm}$. systolic pressure or to $10 \mathrm{~mm}$. pulse pressure) during major surgical operations. The following were evaluated for each drug: optimum dose for a pressor response; maximum systolic and diastolic blood pressures, and rise in systolic and pulse pressure after giving the drug; effect on pulse rate; time taken for the drug to act; duration of action; and side effects on the cardiovascular system. On the basis of the results obtained the clinical effectiveness of the four pressor drugs examined is in this order: methedrine, paredrine, neo-synephrine, pholedrine. The principal criteria on which this opinion is based are: rise of systolic and pulse pressure when the drugs are given to surgical patients with a systolic blood pressure of $80 \mathrm{~mm}$. or less; the speed and duration of action; and the relative freedom from side effects on the cardiovascular system.

The table below summarizes the results obtained.

$\begin{array}{lllcccc} & & & \text { Methedrine } & \text { Paredrine } & \text { Neo-synephrine } & \text { Pholedrine } \\ \text { Satisfactory result } & \ldots & \ldots & 18 & \frac{8}{7} & 13 & 4 \\ \text { Unsatisfactory result } & . & . . & \frac{2}{20} & \frac{12}{20} & \frac{17}{20} & \frac{16}{20}\end{array}$

A result was rated as satisfactory if the systolic pressure remained above $100 \mathrm{~mm}$. and the pulse pressure was not less than $30 \mathrm{~mm}$. for a period of two hours or more. 
Thanks are due to Mr. H. Dodd, Surgeon to the King George Hospital, Ilford, and Mr. Turner Warwick, Surgeon to the Middlesex Hospital, for their assistance and co-operation in this work.

\section{REFERENCES}

Abbott, W. O., and Henry, C. M. (1937). Amer. J. med. Sc., 193, 661.

Altschule, M. D., and Gilman, S. (1939). New Eng. J. Med., 221, 600.

Altschule, M. D., and Iglauer, A. (1940). J. Clin. Invest., 19, 497.

Bittrich, N. M. (1939). Anesth. \& Analg., 17, 44.

Brunner, R. S., and de Takats, G. (1939). Surg. Gynec. Obst., 68, 1021.

Difabio, F. X., Lawrence, J., and Ascione, J. F. (1941). Anesth. \& Analg., 20, 88.

Dodd, H., and Merton, G. (1939). Brit. J. Surg., 27, 78.

Dodd, H. (1942). Lancet, 1, 498.

Prescott, F. (1943a). Brit. med. J., 1, 345.

- Prescott, F. (1943b). Surg. Gynec. Obst., 79, 645.

Iglauer, A., and Altschule, M. D. (1940). J. Clin. Invest., 19, 503.

Iglauer, A., and Molle, W. E. (1943). Amer. Heart J., 26, 247.

Johnson, C. A. (1937). Surg. Gynec. Obst., 65, 458.

Landau, E., Logue, V., and Kopelman, H. (1942). Lancet, 2, 210.

Loman, J., et al. (1939). Amer. Heart J., 18, 89.

Lorhan, P. H., and Oliverio, R. M. (1938). Anesth. \& Analg., 17, 44.

Lorhan, P. H., and Lalich, J. (1940). Ibid., 19, 66.

Myerson, A., and Loman, J. (1941). New Eng. J. Med., 224, 412.

Nathanson, M. H., et al. (1942). Amer. Heart J., 24, 153.

Engelberg, H. (1942). Proc. Soc. Exp. Biol. Med., 51, 239.

Papper, E. M., et al. (1943). J. Amer. med. Ass., 121, 27.

Silvers, H. I., and Leonard, I. E. (1940). Amer. J. Surg., 50, 79. 